\title{
Diffuse infiltrating retinoblastoma
}

\author{
GWYN MORGAN
}

Department of Pathology, Institute of Ophthalmology, University of London

The term "diffuse infiltrating retinoblastoma" was introduced by Ashton (1958) to describe a form of retinoblastoma which did not produce a tumour mass within the retina. Although Manschot (1956) and Weizenblatt (1957) had described such cases previously, they did not recognize the condition as a distinct entity. Schofield (r960) described four cases of this type of retinoblastoma which presented with a hypopyon, and neoplastic cells were demonstrated in the anterior chamber paracenteses.

The purpose of the present paper is to describe a further case of this type of tumour, and to review the ten cases which have been seen in the Pathology Department of this Institute, including the four described by Schofield (1960).

\section{Case report}

\section{GLINICAL FEATURES}

A mentally defective boy aged to years was admitted to hospital with the history of pain in the right $\stackrel{\mathbb{D}}{\longrightarrow}$ eye of several months' duration. There were no other complaints. Ophthalmological examinatiog $\overrightarrow{0}$ of the right eye showed a hypopyon, multiple whitish nodules on the iris, and white vitreous exudates the left eye was normal. Radiographs of the chest showed no abnormality.

TREATMENT

Steroid therapy was begun, but glaucoma, corneal oedema, and an inferior limbal staphyloma ensued. The eye was enucleated.

\section{PATHOLOGY}

Macroscopical examination showed enlargement of the globe (antero-posterior diameter $32 \mathrm{~mm}$; horizontal diameter $29 \mathrm{~mm}$.). There was an inferior limbal staphyloma (Fig. I, opposite), and exudate was present in the anterior chamber and the vitreous. The retina was diffusely thickened but there was no evidence of a tumour mass (Fig. 2, opposite). The optic disc was cupped.

Microscopical examination showed diffuse infiltration of the retina by a retinoblastoma, with no evidence of a tumour mass. The tumour was involving all the layers of the retina and was composed of cells having a little pinkish cytoplasm and hyperchromatic nuclei of varying shapes and sizes. Individual cell necrosis was seen and mitotic figures were fairly common, but there was no evidence of rosette formation (Fig. 3, opposite, and Fig. 4, overleaf).

Discrete foci of tumour cells were seen near the internal limiting membrane of the retina (Fig. $5, \stackrel{N}{N}$ overleaf) and extension into the anterior vitreous had occurred, some of the cells at this site being $N$ viable but most of them being necrotic (Fig. 6, overleaf).

Posteriorly tumour cells had extended into the cupped optic disc but not into the nerve. Anteriorly 0 extension had occurred on to the pars plana (Fig. 7) and ciliary epithelium (Fig. 8), into the iris ${ }_{\odot}$

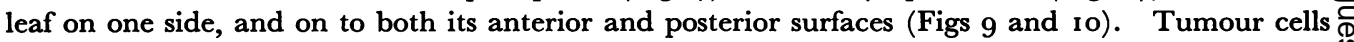
had then extended on to the posterior surface of the cornea, the filtration angle on this side having $\stackrel{\infty}{+}$ 


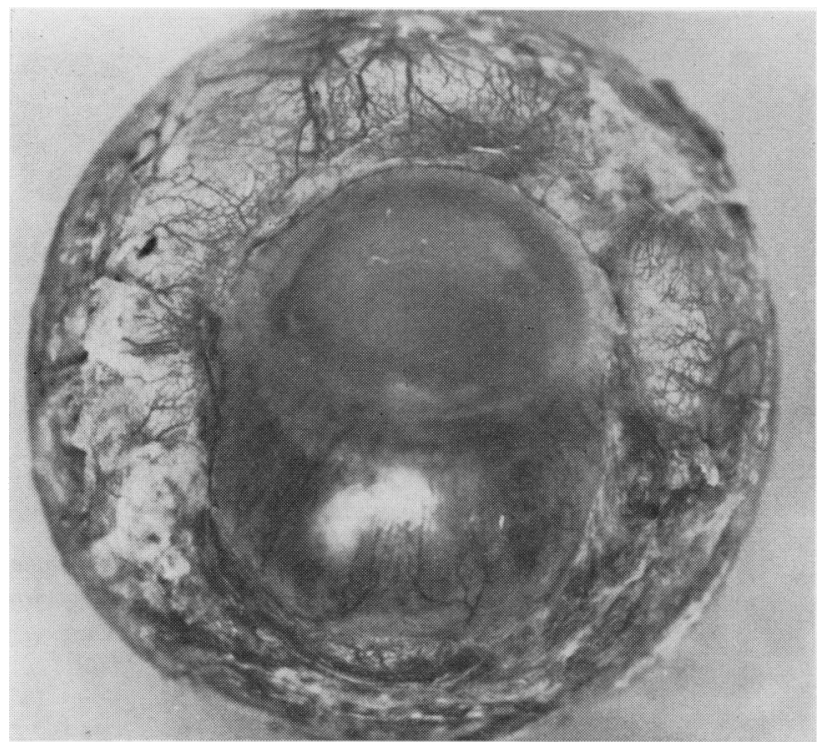

FIG. I Case 10, showing enlarged globe with inferior limbal staphyloma and exudate within the eye

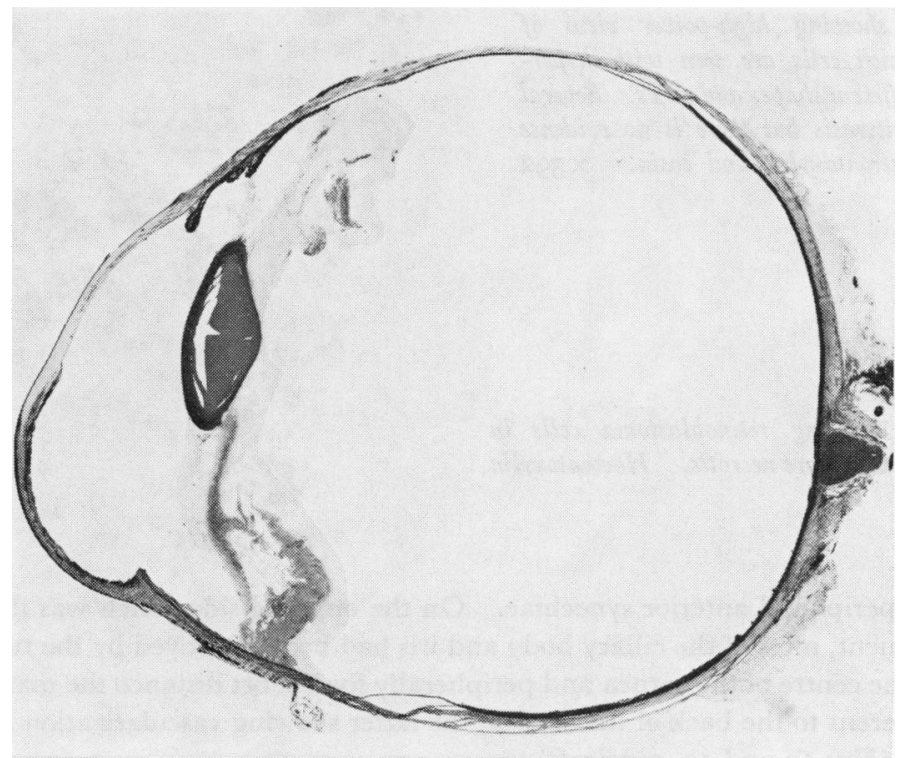

FIG. 2 Case Io, showing diffuse thickening of retina, exudate in anterior vitreous, occlusion of filtration angle, and inferior staphyloma

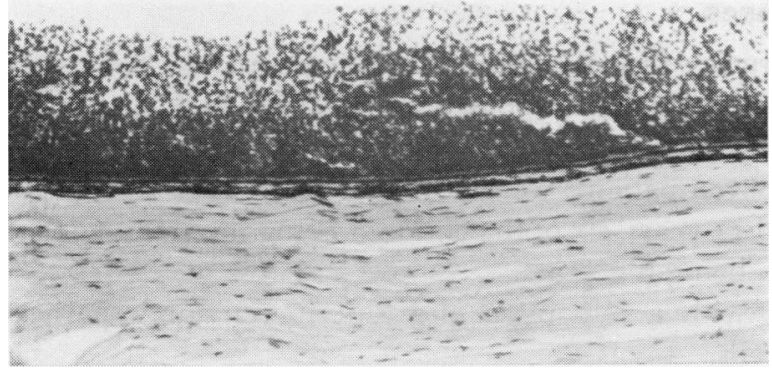

FIG. 3 Case 10, showing low-power view of tumour in which cells are involving all layers of retina. Haematoxylin and eosin. $\times 90$ 


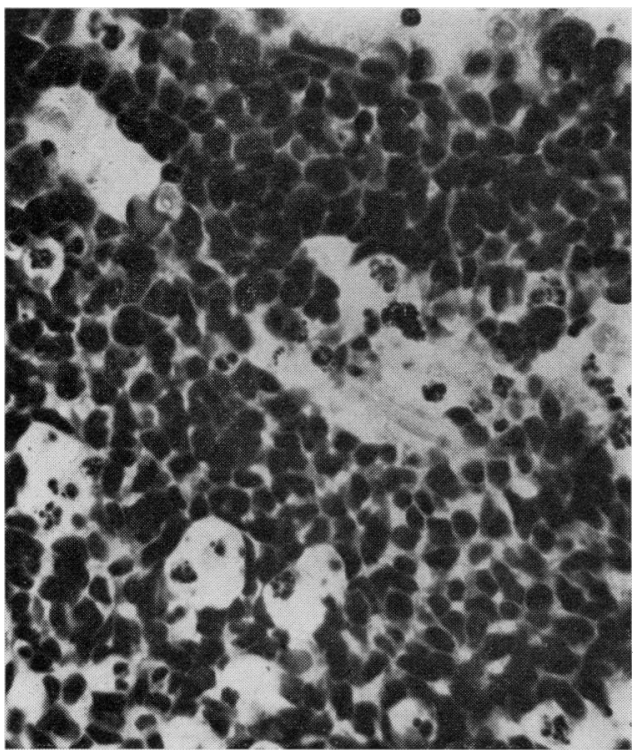

FIG. 4 Case Io, showing high-power view of retinoblastoma in which cells are seen with hyperchromatic nuclei of different shapes and sizes. Several cells are undergoing necrosis but there is no evidence of any rosettes. Haematoxylin and eosin. $\times 392$

FIG. 6 Case 10, showing retinoblastoma cells in vitreous. Most of the cells are necrotic. Haematoxylin and eosin. $\quad \times 90$

been occluded by peripheral anterior synechiae. On the opposite side which was the inferior part of the anterior segment, most of the ciliary body and iris had been destroyed by the tumour (Fig. I I, overleaf). Near the centre of the cornea and peripherally for a short distance the markedly atrophic iris was firmly adherent to the back of the cornea, the latter showing vascularization and infiltration by neoplastic cells (Figs 12 and 13 , overleaf).

\section{Description of other cases}

Ten cases of diffuse infiltrating retinoblastoma, including the case recorded in this paper, have been studied, and the findings are analysed in the Table (p. 605), which shows that in all cases the growth was entirely diffuse, there being no focal tumour mass. None of the tumours was bilateral. Seven patients were boys and three were girls. The age at onset varied between I year and I I years, six of the children being more than 6 years old and the average age for the group being $6 \cdot 2$ years.

Six children presented with a hypopyon and anterior chamber paracentesis in four of these showed tumour cells. 


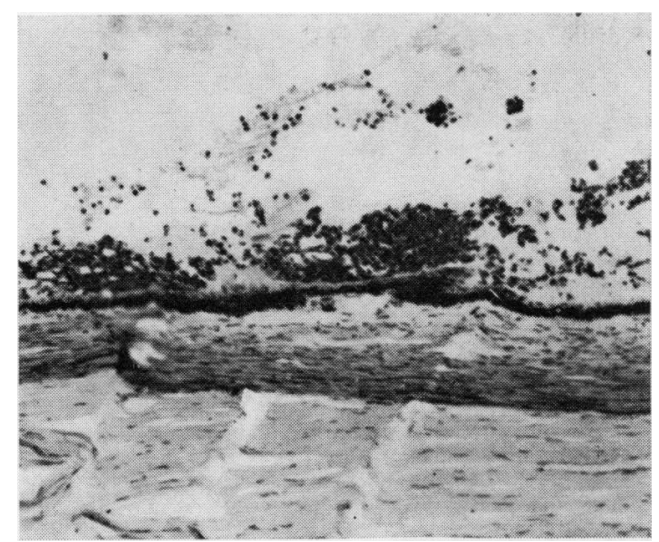

FIG. 7 Case I0, showing retinoblastoma cells on pars plana. Haematoxylin and eosin. $\times 90$

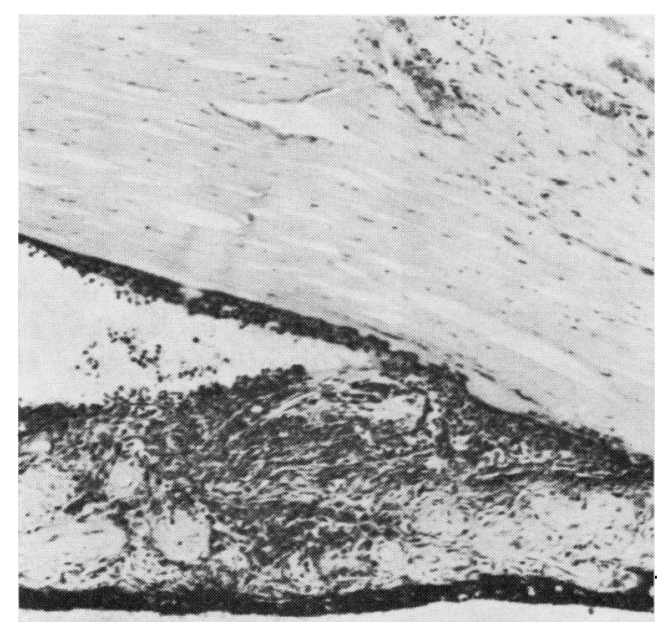

FIG. 9 Case I0, showing infiltration of iris stroma by neoplastic cells which are also present on anterior iris surface and posterior corneal surface. Haematoxylin and eosin. $\times 90$

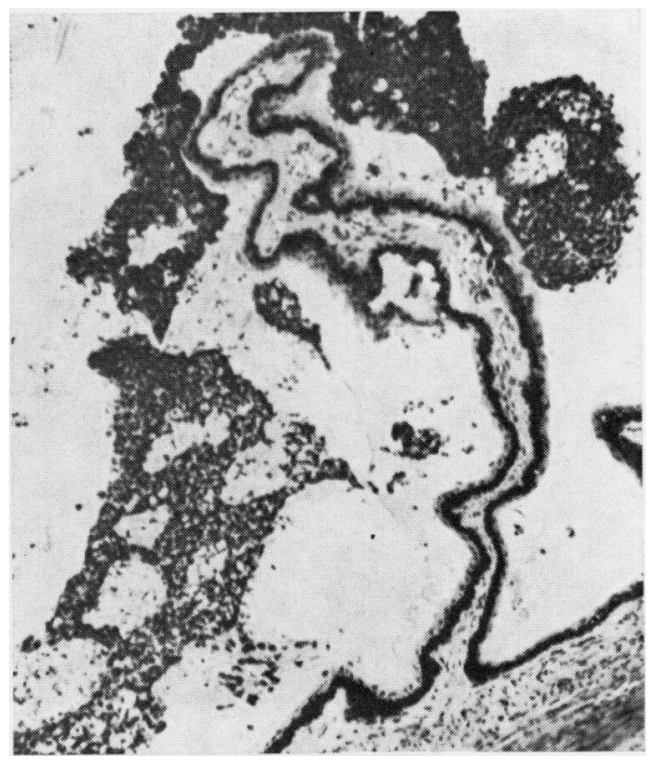

FIG. 8 Case Io, showing neoplastic cells on ciliary epithelium and surrounding a ciliary process. Haematoxylin and eosin. $\quad \times 90$

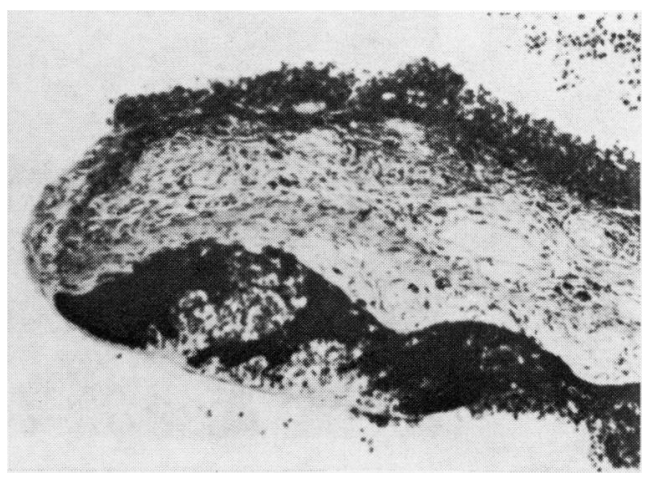

FIG. Io Case 10, showing tumour cells on both surfaces of iris. Haematoxylin and eosin. $\times 90$

Histological examination of the eyes showed in every case that all layers of the retina were involved by a diffuse infiltration of closely packed cells with little cytoplasm and hyperchromatic nuclei of varying shape and size. Mitotic activity and cellular necrosis were moderate, and there was no evidence of rosette formation. Infiltration of the ciliary body, iris, and anterior chamber had occurred in eight cases, with extension into the trabecular meshwork in four of them. Neoplastic cells were seen in the vitreous in every case, in the optic nerve head in four cases, and in the optic nerve and choroid in one case.

At the present time all ten patients are alive and well, the survival times varying between 2 and 17 years (average $9 \cdot 3$ ). The apparently good prognosis is illustrated by the fact that Case 3 (Table) has survived for I4 years without recurrence or metastases despite infiltration of the trabecular meshwork by tumour cells, and that Case 7 has survived for 8 years despite invasion of the choroid. 


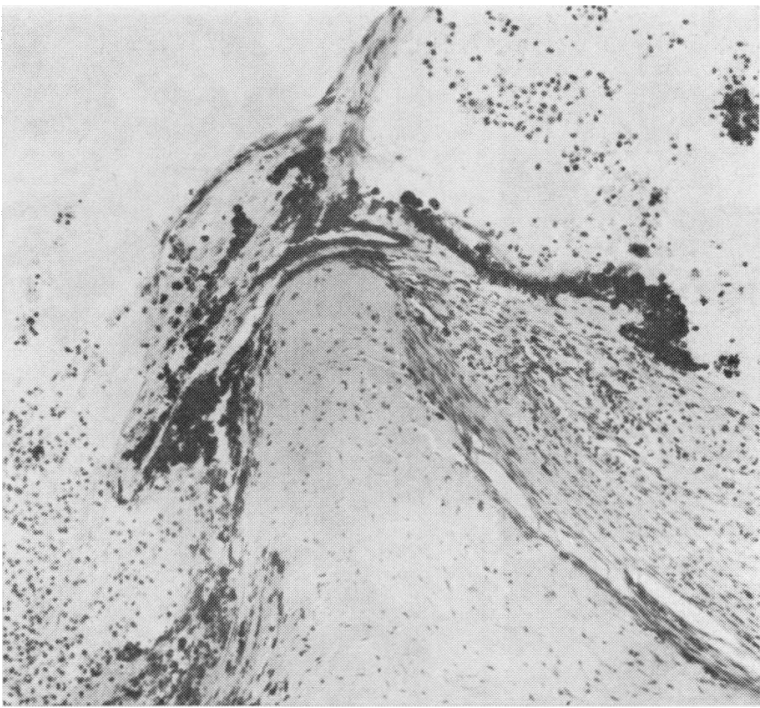

FIG. I I Case 10, showing extensive $\frac{\overline{\bar{c}}}{\overline{9}}$ destruction of ciliary body and iris by $\overrightarrow{\widetilde{\sigma}}$ tumour. Haematoxylin and eosin. $\times 90$

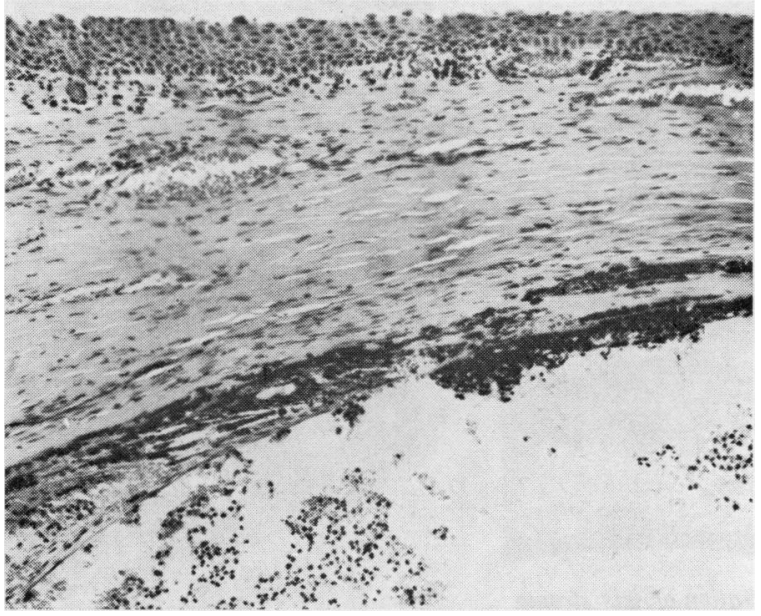

FIG. 12 Case 10, showing markedyy atrophic iris leaf firmly adherent to back $f$ vascularized cornea. Haematoxylin a eosin. $\times 90$

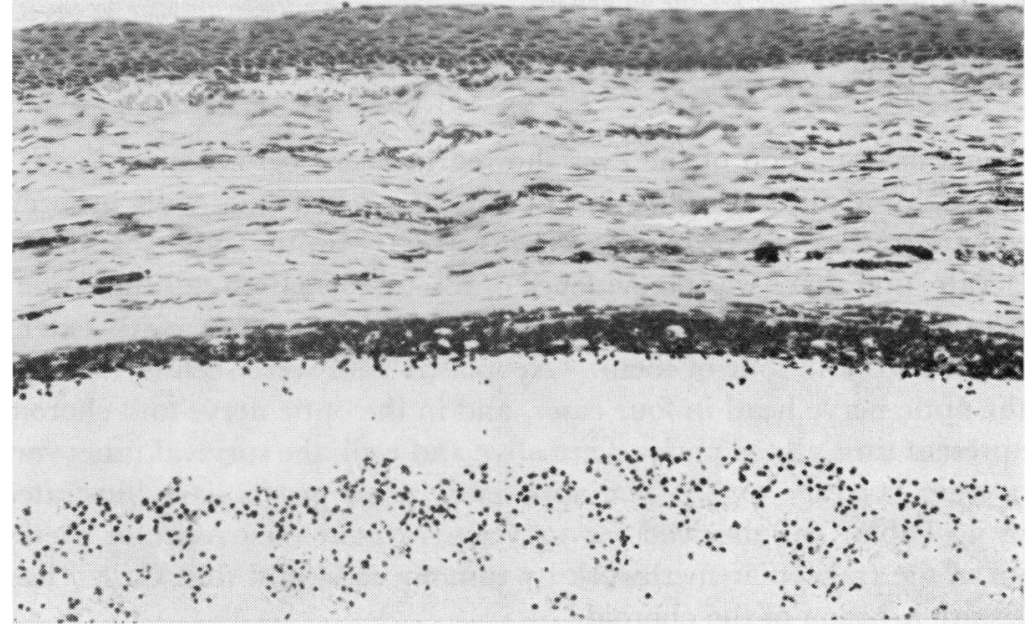

FIG. 13 Case 10 , showing infitration of을. cornea by neoplastic cells. Haematoxylin? and eosin. $\times 130$ 
Table Summary of ten cases of diffuse infiltrating retinoblastoma

\begin{tabular}{|c|c|c|c|c|c|c|}
\hline $\begin{array}{l}\text { Case } \\
\text { no. }\end{array}$ & $\begin{array}{l}\text { Age } \\
(y r s)\end{array}$ & Sex & $\begin{array}{l}\text { Clinical features and ancillary } \\
\text { investigations }\end{array}$ & Pathology & Treatment & Follow-up \\
\hline 1 & $9 \frac{1}{2}$ & $\mathbf{M}$ & $\begin{array}{l}4 \text { mths' history of uveitis with } \\
\text { hypopyon } \\
\text { Neoplastic cells seen in anterior } \\
\text { chamber paracentesis }\end{array}$ & $\begin{array}{l}\text { Diffuse involvement of retina with } \\
\text { no rosettes } \\
\text { Tumour cells in ciliary body, iris, } \\
\text { anterior chamber, and vitreous }\end{array}$ & Enucleation & $\begin{array}{l}\text { Alive and well } \\
\text { without recurrence } \\
\text { or metastases } 17 \\
\text { yrs after onset }\end{array}$ \\
\hline 2 & $\mathbf{I}$ & $\mathbf{M}$ & $\begin{array}{l}\text { Presented with hypopyon and } \\
\text { buphthalmos } \\
\text { Neoplastic cells seen in anterior } \\
\text { chamber paracentesis }\end{array}$ & $\begin{array}{l}\text { Diffuse involvement of retina with } \\
\text { no rosettes } \\
\text { Tumour cells in subretinal space, } \\
\text { ciliary body, iris, vitreous, and } \\
\text { anterior chamber }\end{array}$ & Enucleation & $\begin{array}{l}\text { Alive and well } \\
\text { without recurrence } \\
\text { or metastases } 13 \\
\text { yrs after onset }\end{array}$ \\
\hline 3 & $6 \frac{1}{2}$ & $\mathbf{M}$ & $\begin{array}{l}\text { Presented with hypopyon, } \\
\text { subluxated cataractous lens, } \\
\text { and raised intraocular pressure } \\
\text { Neoplastic cells seen in anterior } \\
\text { chamber paracentesis }\end{array}$ & $\begin{array}{l}\text { Diffuse involvement of retina with } \\
\text { no rosettes } \\
\text { Tumour cells in vitreous, ciliary } \\
\text { body, iris, anterior chamber, } \\
\text { and trabecular meshwork }\end{array}$ & Enucleation & $\begin{array}{l}\text { Alive and well } \\
\text { without recurrence } \\
\text { or metastases } 14 \\
\text { yrs after onset }\end{array}$ \\
\hline 4 & $4 \frac{3}{4}$ & $\mathbf{F}$ & $\begin{array}{l}\text { Cobalt treatment for retino- } \\
\text { blastoma } 2 \text { yrs before onset of } \\
\text { hypopyon and cataract } \\
\text { Neoplastic cells seen in anterior } \\
\text { chamber paracentesis }\end{array}$ & $\begin{array}{l}\text { Diffuse involvement of retina with } \\
\text { no rosettes } \\
\text { Tumour cells in vitreous, ciliary } \\
\text { body, iris, and anterior chamber } \\
\text { Calcification of retina at site of } \\
\text { original lesion }\end{array}$ & Enucleation & $\begin{array}{l}\text { Alive and well } \\
\text { without recurrence } \\
\text { or metastases } 14 \\
\text { yrs after onset }\end{array}$ \\
\hline 5 & I I & $\mathbf{F}$ & $\begin{array}{l}\text { Hypopyon for } 3 \text { mths with raised } \\
\text { intraocular pressure } \\
\text { ESR, WR, and radiograph of } \\
\text { globe normal }\end{array}$ & $\begin{array}{l}\text { Diffuse involvement of retina with } \\
\text { no rosettes } \\
\text { Tumour cells in vitreous, ciliary } \\
\text { body, iris, anterior chamber, } \\
\text { trabecular meshwork, a scleral } \\
\text { channel, subretinal space, and } \\
\text { optic nerve head }\end{array}$ & Enucleation & $\begin{array}{l}\text { Alive and well } \\
\text { without recurrence } \\
\text { or metastases } 3 \\
\text { yrs after onset }\end{array}$ \\
\hline 6 & 7 & $\mathbf{M}$ & $\begin{array}{l}\text { "Peculiar-looking" eye for } 3 \text { mths } \\
\text { in a mentally backward child } \\
\text { Dense grey lesion almost } \\
\text { completely covering fundus }\end{array}$ & $\begin{array}{l}\text { Diffuse involvement of retina with } \\
\text { no rosettes } \\
\text { Tumour cells in vitreous }\end{array}$ & Enucleation & $\begin{array}{l}\text { Alive and well } \\
\text { without recurrence } \\
\text { or metastases ro } \\
\text { yrs after onset }\end{array}$ \\
\hline 7 & 3 & $\mathbf{F}$ & $\begin{array}{l}\text { Mother noticed white pupil } 2 \text { yrs } \\
\text { previously } \\
\text { Signs of iritis and cataract on } \\
\text { examination } \\
\text { Chest } x \text { ray and ESR normal }\end{array}$ & $\begin{array}{l}\text { Diffuse involvement of retina with } \\
\text { no rosettes } \\
\text { Tumour cells in vitreous, ciliary } \\
\text { body, iris, anterior chamber, } \\
\text { trabecular meshwork, optic } \\
\text { nerve, and choroid }\end{array}$ & Enucleation & $\begin{array}{l}\text { Alive and well } \\
\text { without recurrence } \\
\text { or metastases } 8 \\
\text { yrs after onset }\end{array}$ \\
\hline 8 & 6 & $\mathbf{M}$ & $\begin{array}{l}\text { Treated as a case of "retinal } \\
\text { haemangiomatosis" Io mths } \\
\text { previously } \\
\text { Recently developed iris deposits } \\
\text { and aqueous flare }\end{array}$ & $\begin{array}{l}\text { Diffuse involvement of retina with } \\
\text { no rosettes } \\
\text { Tumour cells in vitreous, sub- } \\
\text { retinal space, ciliary body, iris, } \\
\text { anterior chamber, trabecular } \\
\text { meshwork, and optic nerve head }\end{array}$ & Enucleation & $\begin{array}{l}\text { Alive and well } \\
\text { without recurrence } \\
\text { or metastases } 7 \\
\text { yrs after onset }\end{array}$ \\
\hline 9 & 34 & $\mathbf{M}$ & $\begin{array}{l}\text { White pupil noticed by mother } \\
\text { for several wks }\end{array}$ & $\begin{array}{l}\text { Diffuse involvement of retina with } \\
\text { no rosettes } \\
\text { Tumour cells in vitreous and } \\
\text { optic nerve head }\end{array}$ & Enucleation & $\begin{array}{l}\text { Alive and well } \\
\text { without recurrence } \\
\text { or metastases } 5 \\
\text { yrs after onset }\end{array}$ \\
\hline 10 & 10 & $\mathbf{M}$ & $\begin{array}{l}\text { Endophthalmitis and hypopyon } \\
\text { for } 8 \mathrm{mths} \\
\text { Inferior staphyloma for I mth } \\
\text { with secondary glaucoma } \\
\text { Child mentally defective }\end{array}$ & $\begin{array}{l}\text { Diffuse involvement of retina with } \\
\text { no rosettes } \\
\text { Tumour cells in ciliary body, iris, } \\
\text { anterior chamber, vitreous, and } \\
\text { cupped optic disc }\end{array}$ & Enucleation & $\begin{array}{l}\text { Alive and well } \\
\text { without recurrence } \\
\text { or metastases } 2 \\
\text { yrs after onset }\end{array}$ \\
\hline
\end{tabular}

$\mathrm{ESR}=$ erythrocyte sedimentation rate

WR $=$ Wassermann reaction

\section{Discussion}

Of 720 cases of retinoblastoma examined histologically in the Department of Pathology of this Institute between the years 1949 and 1970 , only ten ( $1 \cdot 4$ per cent.) have been diagnosed as diffuse, infiltrating tumours. Several interesting features have emerged from the study of these ten cases. The average age of the patients is higher than that of the usual type of retinoblastoma which presents with a tumour mass, and none of these tumours was bilateral. Patients frequently present with a hypopyon so that examination of an anterior chamber paracentesis for neoplastic cells is an important diagnostic procedure. Rosettes are not a feature of this tumour, and as far as this small series of cases is concerned the tumours have a good prognosis. 
The tumour originates either as a simple diffuse growth or as multiple foci of growf which coalesce. Spread may then occur through the ciliary body and iris and exter into the anterior chamber, and may in some cases invade the trabecular meshwork Tumour cells may grow into the vitreous or upon the pars plana and ciliary processes. Invasion of the choroid or optic nerve occurs in some cases.

In seven of the ten cases presenting with this tumour, the age of the patient was years or over, suggesting that the neoplasms arise at a later age than the usual type of tumour. In three of the cases, however, the age at onset was I year (Case 2), I ye (Case 7), and 3 years (Case 9) respectively, which shows that the tumour can arise at am earlier age and that some (Cases 2 and 9) may grow more rapidly than others, although there were no histological features to account for this. On the whole, however, the rate of growth is slow, as illustrated by Case 4 in which the original lesion was treated by cobalt irradiation 2 years before the onset of a hypopyon, and by Gase 7 in which the mother noticed a white pupil 2 years before bringing the child to hospital. A rapidlw. growing tumour would be expected to produce an expanding growth within the area of the retina while a slowly-growing tumour would be more likely to spread through thef retina. There seems to be little doubt that the tumour must have a low malignaint potential which would explain the apparently favourable prognosis of this uncommo neoplasm, for in spite of invasion of the trabecular meshwork in four cases (Cases 3, 5, 7 , and 8 ) and of the choroid in one (Case 7), the patients have survived with no evidengf of recurrence or metastases for periods varying between 3 and i 4 years after enucleatio The question whether or not the low malignant potential is due to the tumours' origin from more highly differentiated tissue is not clear, because the rosettes seen in the better differet tiated retinoblastomas were not observed in the ten cases of this series. It is possible, however, that they were absent because the tumour did not produce a mass, and tiere was insufficient space within the retina for their development.

\section{Summary}

Ten cases have been described of a type of retinoblastoma which is both diffuse an infiltrating, and which does not form a tumour mass; four of these cases have been reporte⿳⺈ previously (Schofield, 1960). The average age of the patients is higher than that foun in the usual type of retinoblastoma, and the majority present for the first time with a hypopyon. Bilaterality was not a feature, and rosette formation was not seen. The prognosis after enucleation appears to be good.

I am most grateful to Prof. Norman Ashton for his advice during the preparation of this paper.

\section{References}

AShton, N. (1958) Quoted by Schofield (196o).

MANSGHOT, W. A. (1956) Ophthalmologica (Basel), 132, 162

SCHOFIELD, P. B. (1960) Brit. J. Ophthal., 44, 35

weizenblatt, s. (I957) A.M.A. Arch. Ophthal., 58, 699 